\title{
Determinants of the Quality Regional Financial Statement
}

\author{
Anggeraini Oktarida ${ }^{1, *}$, Eka Jumarni Fithri ${ }^{2}$, Lambok Vera Riama ${ }^{3}$, Sri Hartaty ${ }^{4}$ \\ ${ }^{1-4}$ Department of Accounting, State Polytechnic of Sriwijaya, Palembang, Indonesia \\ *Corresponding Author Email: anggraini_oktarida@polsri.ac.id
}

\begin{abstract}
This study aims to determinante the Quality Regional Financial Statements on the Regional Financial and Asset Management Agency of Palembang City. This data was obtained from a questionnaire in the form of questions distributed to employees at the Regional Financial and Asset Management Agency of Palembang City. The population of this research is all employees in the Regional Financial and Asset Management Agency of Palembang City, amounting to 83 people. Sampling using saturated sampling. The research method uses quantitative methods with the SPSS program Version 20.0 and with an R Square value of 0.616. The findings of this study indicate that the influence of the variable Utilization of Accounting Information Technology, Internal Control Systems, Good Governance and Organizational Commitment on research simultaneously shows that a significant positive effect on the Quality of Regional Financial Statements. The partial results of the study indicate that the variable Good Governance and Organizational Commitment has a significant positive effect on the Quality of Regional Financial Statements.
\end{abstract}

Keywords: Good Governance, Organizational Commitment, report quality

\section{INTRODUCTION}

Rapid technological progress, is very helpful in the management of government to realize good governance. The use of information technology by the Central Government and Local Governments is regulated in Government Regulation [1] concerning Regional Financial Information Systems which is a substitute for Government Regulation No. 11 of 2001 concerning regional financial information, speed of transaction processing and report preparation, accuracy of calculations, storage of large amounts of data, lower processing costs and multiprocessing capabilities.

The Internal Control System is expected to avoid the risk of fraud, irregularities and corruption. It is necessary to manage village fund allocations in a professional, effective, efficient and accountable manner based on the principles of public management. Minister of Home Affairs Regulation [2] concerning Guidelines for Village Financial Management is expected to be a guideline in the management of village finances in particular the allocation of village funds to realize good governance.

The implementation of good governance is a prerequisite for every government to realize the aspirations of the people and achieve the goals and ideals of the nation state [3]. Good Governance must ensure that there is an appropriate and accurate disclosure for every problem related to governance, that is, financial reports, government performance, government regulations and are prepared in accordance with high quality standards. The organizational commitment of employees within the organization also contributes to the quality of regional financial reports.

Organizational commitment is related to the level of involvement of people with the organization where they work and are interested in staying in the organization and the person's willingness to improve themselves and show loyalty to the organization because they feel themselves involved in organizational activities. The higher organizational commitment will have an impact on employees will survive in the organization and will always improve its performance [4]. High employee performance will produce good quality financial reports. Subsequent regional government financial reports will be audited and get an opinion from the Supreme Audit Board (BPK). Fair Opinion Without Exception (WTP) on the 2013-2017 regional government financial report of Palembang City issued by the Indonesian National Audit Board [5].

\section{LITERATURE REVIEW}

The benefits information technology expected by users of information systems in carrying out their duties or behavior in using technology when doing work. The measurement is based on the intensity of utilization, the frequency of utilization and the number of applications or software used [6] in [7]. 
Government oversight increases financial accountability through evaluation and improvement of internal control, risk management and governance processes. The Purpose of the Government Internal Control System according to Government Regulation [8] to provide adequate confidence about; effective and efficient activities, reliable financial reports, securing state assets and compliance with laws and regulations.

Local governments are required to apply the principles of good governance. The concept of good governance must have the support of commitment from all parties, namely the state / government, private and society. The principles that need to be considered for implementing Good Governance in the administration of regional government according to Minister of SOE Regulation [9] namely: Transparency, Independence, Accountability, Accountability, Fairness Employees must have organizational commitment to achieve organizational goals.

Organizational commitment as the level where a person recognizes an organization and is bound to its goals [10]. This is an important work attitude to be held by an employee because organizational commitment shows the willingness of employees to work harder in achieving organizational goals.

Government Regulation [11] concerning Government Accounting Standards (SAP) states "Financial statements are structured reports about the financial position and transactions carried out by a reporting entity"

According to Permendagri [12] that:

Regional financial statements are all the rights and obligations of the region in the context of carrying out regional government which can be valued in money including all forms of wealth related to the rights and obligations of the region.

A complete financial statement usually includes a balance sheet, income statement, income statement, statement of changes in financial position (presented in various ways such as cash flow statement, or cash flow statement), notes, and other reports as well as an explanation of an integral part of the financial statements [13].

\section{RESEARCH METHODOLOGY}

\subsection{Data Quality Testing}

A complete financial statement usually includes a balance sheet, income statement, income statement, statement of changes in financial position (presented in various ways such as cash flow statement, or cash flow statement), notes, and other reports as well as an explanation of an integral part of the financial statements.

There are four characteristics of the normative prerequisites required for a government financial report, namely [14]:

1. Relevant

2. Reliable

3. Can be compared

4. Can be understood

\subsection{Framework}

The use of accounting information technology by the Central and Local Governments accelerates transaction processing and report preparation, accuracy of calculations, storing large amounts of data, lower processing costs, multiprocessing capabilities. The Internal Control System is expected to avoid the risk of fraud, irregularities and corruption. The management of village fund allocations is carried out in a professional, effective, efficient and accountable manner based on public management principles. Good governance has become a central issue, where with the era of globalization demands will be good governance in line with increasing public knowledge. Good governance (good governance) is an agreement relating to state regulations created jointly by the government, civil society and the private sector. Organizational Commitment is a bond of employees who feel they have an agency that is proven by their values, goals and objectives. Based on the description above, it will appear in the following research paradigm drawings in Figure 1: 


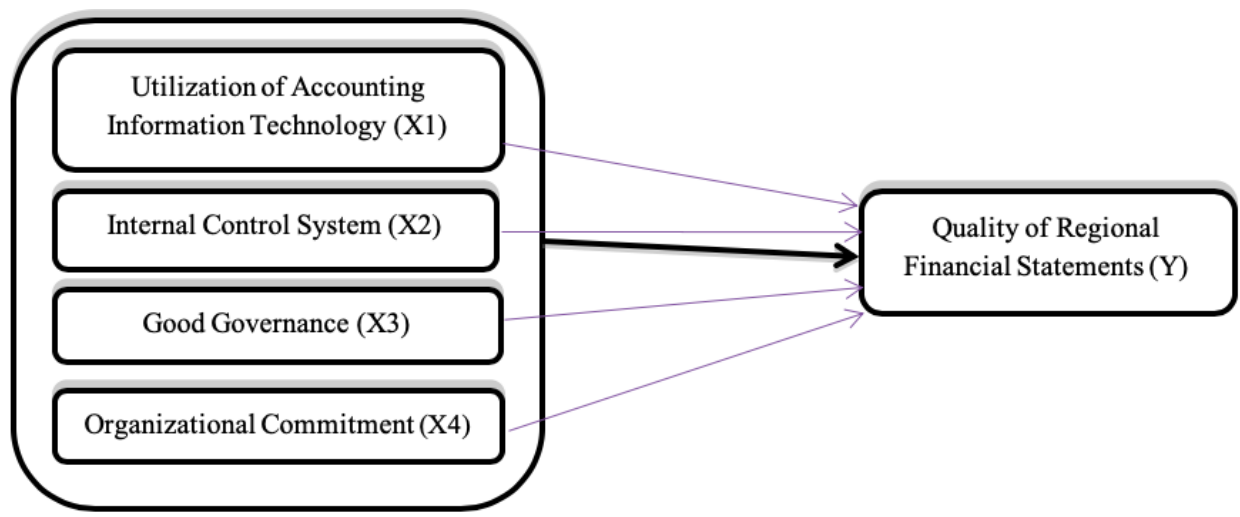

Figure 1 Research paradigma

Overall data quality testing was performed using SPSS 22.0 software.

\section{Validity test}

The results of testing the validity of the statement used in the variable Utilization of Accounting Information Technology (X1), Internal Control Systems (X2), Good Governance (X3) and Organizational Commitment (X4) and Quality of Financial Statements (Y). The calculated $r$ value for all instrument statements as a whole is the calculated $r$ value $>$ from the $r$ table value $(0.285)$, so that the whole statement above can be said to be valid.

Reliability Test

The reliability test results in the questionnaire instrument used in this study. The reliability test results show the Cronbanch Alpha value is the Information Technology Utilization variable 0.950, Internal Control 0.909, Good Governance 0.949, Organizational Commitment 0.813 and Financial Report Quality 0.838, so the questionnaire instruments used can be said to be reliable because it is greater than the level of significance that is 0.6 and has a very high level of significance because it is in the range 0.813 to 0.950 .

\section{RESULTS AND DISCUSSION}

\subsection{Classical Assumption Test}

Normality test

The Kolmogorov-Smirnov One Sample Test results in the table above show that the residual probability value ( $p$ value) in this study has a value greater than 0.05 , which is equal to 0.220 . This means that residual data are normally distributed.

Multicollinearity Test

The tolerance value of each variable is greater than 0.1 and the VIF value is smaller than 10 so that it can be stated that there is no multicollinearity problem in this research model.

Heterokedasticity Test

The significance value of the four independent variables is more than 0.05 . Thus it can be concluded that there is no heteroscedasticity problem in the regression model.

Autocorrelation Test

The results of Durbin-Watson are 1,933, while from the results of the DW table with a significant 0.05 with the number of data $\mathrm{n}=75$ and the number of independent variables $\mathrm{k}=4$ produces a DL value of 1.5151 and DU of 1.7390 , according to the criteria of DU $<\mathrm{DW}<4-\mathrm{DU}$ $(1.7390<1.933<2.261)$ it can be concluded that the study did not occur autocorrelation.

\subsection{Analysis of Multiple Linear Regression}

The results of multiple linear regression test, it can be seen the regression equation of the Quality of Regional Financial Statements

$=2.448+0.588 \times 1+0.528 \times 2+-0.019 \times 3+0.237 \mathrm{X} 4$

An explanation of the above equation is as follows:

- The constant value (a) is 2,448

This regression model has a positive constant value of 2.448. it means that if the value of the variable Utilization of Information Technology, Internal Control System Good Governance and Organizational Commitment, is 0 then the value of the Quality of

Regional Financial Statements is positive at 2.448.

- Coefficient value (b1) of 0.588

This regression equation model has a positive coefficient value of 0.588 . Figures 0.588 means that every increase in the Utilization of Information Technology will result in an increase in the quality of the Regional Financial Statements of 0.588 with the assumption that the other independent variables are of fixed value.

- Coefficient value (b2) of 0.528 
This regression equation model has a positive coefficient value of 0.528 . Figures 0.528 means that each increase in the Internal Control System will result in an increase in the Quality of the Regional Financial Statements of 0.528 with the assumption that the other independent variables are of fixed value.

- Coefficient value (b3) of -0.19

This regression equation model has a negative coefficient of -0.19 .

- Coefficient value (b4) of 0.237

This regression equation model has a positive coefficient value of 0.237 . Figures 0.237 means that every increase in Organizational Commitment will increase the Quality of Regional Financial Statements by 0.237 with the assumption that other independent variables are of fixed value.

\subsection{Hypothesis Test}

The hypothesis is a temporary answer to the formulation of the research problem, where the research problem formulation has been stated in the form of sentence questions. Then the results of the Hypothesis Test are used to answer the sentence questions that have been stated by this study in the formulation of the problem.

The following tests are used by researchers, namely:

a. Determination Coefficient Test (R2).

The statistical calculation results obtained an $\mathrm{R}$ value of 0.879 which shows a very close relationship between the variable Utilization of Information Technology, Internal Control Systems Good Governance and Organizational Commitment, because the value approaches 1 . The adjusted value of 0.773 , this means $77.3 \%$ variation in the Quality of Financial Statements Regions can be explained by variations of the four variables of Independence, Good Governance, Organizational Commitment, Utilization of Information Technology and Internal Control, while the rest $(100 \%-77.3 \%=22.7 \%)$ is explained by other causes outside the model.

b. F Test (Simultaneous)

The results of simultaneous testing (F Test) on all the independence variables in this study will be explained through Table 1 and discussion.

Table 1 Simultaneous Test Results (F Test)

\begin{tabular}{|ll|l|l|l|l|l|}
\hline Model & & Sum of Squares & Df & Mean Square & F & Sig. \\
\hline \multirow{4}{*}{1} & Regression & 2120.339 & 4 & 530.085 & 59.747 & $.000^{\mathrm{b}}$ \\
& Residual & 621.048 & 70 & 8.872 & & \\
& Total & 2741.387 & 74 & & & \\
\hline
\end{tabular}

a. Dependent Variable: Y

b. Predictors: (Constant), X4, X1, X2, X3

Source: SPSS output processed (2018)

Based on Table 1, it can be seen that the F-calculated value is 59.747 and the significance is 0.00 . This indicates that the F-count of 59.747 is greater than the F-table of 2.503 , so it can be stated that simultaneously the independent variables: Utilization of Information Technology (X1), Internal Control System (X2), Good
Governance (X3), and Organizational Commitment ( X4), together affect the dependent variable Quality of Regional Financial Statements (Y).

c. T test (partial). Partial test results (t) can be seen in the Table 2.

Tabel 2 Result of Significance of t Value

Coefficients $^{\mathrm{a}}$

\begin{tabular}{|c|c|c|c|c|c|}
\hline Model & Unstandardize & Coefficients & Standardized Coefficients & $\mathrm{T}$ & Sig. \\
\hline & $\mathrm{B}$ & Std. Error & Beta & & \\
\hline (Constant) & 2.448 & 2.221 & & 1.102 & .274 \\
\hline $\mathrm{X} 1$ & .588 & .155 & .402 & 3.792 & .000 \\
\hline $\mathrm{X} 2$ & .528 & .175 & .351 & 3.019 & .004 \\
\hline $\mathrm{X} 3$ & -.019 & .059 & -.031 & -320 & .750 \\
\hline $\mathrm{X} 4$ & .237 & .111 & .351 & 2.144 & .036 \\
\hline
\end{tabular}

a. Dependent Variable: Y

Source: SPSS output processed (2018) 
Based on the Table 2, it can be seen the value of t-count and the degree of significance of each independent variable $(\mathrm{X} 1, \mathrm{X} 2, \mathrm{X} 3, \mathrm{X} 4)$ which is an indicator of acceptance and rejection of the hypothesis. The results of testing the hypothesis through a partial test (t test) in detail are explained as follows:

a) A constant value of $2.448 \%$ means that if the factors that influence the quality of the auditor are 0 then the effect is positive.

b) In the Independent variable (X1) the t value is 3.792 .

The results obtained for the table of 1,994. Because $t$ count $>t$ table $(3,792>1,994)$ so it can be said that the independent variable Utilization of Information Technology (X3) has an influence on the dependent variable Quality of Regional Financial Statements (Y). Then it can be seen that Hal is accepted and Hol is rejected, meaning that it can be concluded that the Use of Information Technology has a partial significance effect on the Quality of Regional Financial Statements.

c) In the Independent variable (X2) the t value is 3.019.

The results obtained for the table of 1,994. Because the value of tcount $>$ ttable $(3,019>1,994)$ so it can be said that the Independent Internal Control variable (X4) has an influence on the dependent variable Quality of Regional Financial Statements (Y). Then it can be seen that Ha1 is accepted and Hol is rejected, meaning it can be concluded that Internal Control has a partial significance effect on the Quality of Regional Financial Statements.

d) In the Independent variable (X3) the t value is -0.320 . The results obtained for the table were 1,993. Because the value of $t$ count $>t$ table $(-0.320>1.994)$ so it can be said that the independent variable Good Governance (X1) has no influence on the dependent variable Quality of Regional Financial Statements (Y). This means that it can be concluded that Good Governance does not have a significant effect partially on the Quality of Regional Financial Statements.

e) In the Independent variable (X4) the t value is 2.144.

The results obtained for the table of 1,994 (see the statistics table). Because the value of $t$ count $>t$ table $(2.144>1.994)$ so it can be said that the Independent variable Organizational Commitment (X2) has an influence on the dependent variable Quality of Regional Financial Statements (Y). Then it can be seen that Ha1 is accepted and Hol is rejected, meaning it can be concluded that Organizational Commitment has a partial significance effect on the Quality of Regional Financial Statements.

Based on the results of the SPSS output, the researcher will explain and describe the influence of the Utilization of Information Technology, Internal Control Systems, Good Governance, Organizational Commitment, to the Quality of Regional Financial Statements:
4.4. Utilization of information technology, internal control systems, good governance, and organizational commitment, simultaneously has a positive effect on the quality of regional financial reports.

Information Technology Utilization Variable (X1) has tcount> ttable $(3,792>1,994)$. so it can be said that the Independent variable Utilization of Information Technology (X1) has an influence on the dependent variable Quality of Regional Financial Statements (Y). Then it can be seen that Hal is accepted and Hol is rejected, meaning it can be concluded that the Use of Information Technology has a partial significance effect on the Quality of Regional Financial Statements

Internal Control System Variable (X2) has tcount> ttable (3,019> 1,994). so it can be said that the Independent Internal Control (X2) variable has an influence on the dependent variable Quality of Regional Financial Statements (Y). Then it can be seen that Hal is accepted and Hol is rejected, meaning that it can be concluded that Internal Control has a partial significance effect on the Quality of Regional Financial Statements

Good Governance (X3) has a value of $t$ count $>t$ table ($0,320>1,994)$. This means that it can be seen that Good Governance has no partial effect on the Quality of Regional Financial Statements.

Based on the description of the results of the study Organizational Commitment variable (X4) has a value of $t$ count > t table $(2.144>1.994)$. so it can be said that the Independent variable Organizational Commitment (X2) has an influence on the dependent variable Quality of Regional Financial Statements (Y). Then it can be seen that Ha1 is accepted and Hol is rejected, meaning it can be concluded that Organizational Commitment has a partial significance effect on the Quality of Regional Financial Statements.

4.5. Utilization of information technology, internal control systems, good governance, and organizational commitment, simultaneously has a positive effect on the quality of regional financial report

Based on the results of hypothesis testing shows that the Fcalculated value is 59.747 and the significance is 0.00 . This indicates that the F-count of 59.747 is greater than the F-table of 2.503, so it can be stated that simultaneously the independent variables: Utilization of Information Technology (X1), Internal Control (X2), Good Governance (X3), and Organizational Commitment (X4 ), together affect the dependent variable Quality of Regional 
Financial Statements (Y). Thus the researcher's hypothesis can be accepted.

\section{CONCLUSION}

Utilization of Information Technology, Internal Control, Good Governance, and Organizational Commitment, partially has a positive effect on the Quality of Regional Financial Statements can be accepted. Utilization of Information Technology, Internal Control, Good Governance, and Organizational Commitment, simultaneously have a positive effect on the Quality of Regional Financial Statements can be received In this study, determinants are limited to the Utilization of Information Technology, Internal Control Systems, Good Governance, and Organizational Commitment. Not all populations in this study were sampled due to lack of data availability so they did not become research samples and the research was limited to the government in Palembang City's Financial and Asset Management Agency.

The Regional Financial and Asset Management Agency of Palembang City is expected to continue to improve the Utilization of Information Technology, Internal Control Systems, Good Governance, and Organizational Commitment to improve the Quality of Regional Financial Statements

Palembang City Financial and Asset Management Agency, is expected to provide socialization and training for employees to continue to improve the Utilization of Information Technology, Internal Control Systems, Good Governance, and Organizational Commitment to improve the Quality of Regional Financial Statements

\section{REFERENCES}

[1] Peraturan Pemerintah No. 56 of 2005 tentang Sistem Informasi Keuangan Pemerintahan Daerah (Lembaran Negara Republik Indonesia).

[2] Peraturan Menteri Dalam Negeri No 113 Tahun 2014 tentang Pedoman Pengelolaan Keuangan Desa diharapkan dapat menjadi pedoman dalam pengelolaan keuangan desa

[3] Sedarmayanti. 2012. Good Governance \& Good Corporate Governance 3 Edisi Revisi (Soft Cover). Mandar Maju. Bandung

[4] Adifitya, Jajang. 2014. Pengaruh Komitmen Organisasi terhadap Kinerja Karyawan Pada PT. Bukit Makmur Mandiri Utama Site Kideco Jaya Agung Batu Kajang Kabupaten Paser. eJournal Ilmu Administrasi Bisnis, 2014, 2 (4): 833-845, ejournal.adbisnis.fisip-unmul.ac.id. Andrew, Sikula. 2011. Manajemen Sumber Daya Manusia.
[5] Badan Pemeriksa Keuangan Republik Indonesia. 2017. Laporan HasilPemeriksaan BPK RI atas Laporan Keuangan Pemerintah Kota Palembang Anggaran 2016.

[6] Thomson, Ronald L. Higgins, Christhoper A and Howell, Jane M. 1991. Personal Computing, Toward a Conceptual Model of Utilization. MIS Quartely

[7] Wijana. 2007. Pengaruh Pemanfaatan Teknologi Informasi Dan Pengendalian Intern Terhadap Kinerja Instansi Pemerintah

[8] Peraturan pemerintah Republik Indonesia No. 60 Tahun 2008, tentang Sistem Pengendalian Intern Pemerintah

[9] Peraturan Menteri BUMN No.PER/01/MBU/2011 tentang Penerapan tata kelola perusahaan yang baik ( Good Corporate governance) pada Badan Usaha Milik Negara

[10] Kreitner, Robert dan Angelo Kinicki (2014). Organizational Behavior. New York: McGraw-Hil

[11] Peraturan pemerintah Republik Indonesia Nomor 71 Tahun 2010, tentang Standar Akuntansi Pemerintahan.

[12] Permendagri Nomor 13 Tahun 2006 tentang Pengelolaan Keuangan Daerah

[13] Ikatan Akuntan Indonesia (IAI). 2016.Standar Akuntansi Keuangan. Salemba Empat. Jakarta

[14] Komite Standar Akuntansi Pemerintah. 2006. Standar Akuntansi Pemerintah. Jakarta. 